\title{
THE AVALONIAN AND NASHOBA TERRANES, EASTERN MASSACHUSETTS, U.S.A.: AN OVERVIEW
}

\author{
J. Christopher Hepburn*, Malcolm Hil1**, and Rudolph Hon* \\ * Department of Geology and Geophysias, Boston College \\ Chestnut Hill, Massachusetts 02167 \\ **Department of Geology, 14 HO, Northeastern University \\ Boston, Massachusetts 02115
}

Date Received July 7, 1986

Date Accepted February 16, 1987

\begin{abstract}
Three major fault-bounded terranes comprise the eastern margin of the Appalachian Orogen in the vicinity of Boston, Massachusetts. Each has a distinctive geological history. The easternmost, the Boston-Avalon Zone, contalns features common to Avalonian terranes in the northern Appalachians. These include voluminous Late Proterozoic (650-600 Ma) calc-alkaline granitic to dioritic plutons and related volcanic rocks associated with the "maln phase" of Avalonian thermal activity. These are covered by a thin veneer of Late Proterozolc to Early Paleozolc sedimentary rocks and fluviatile Carboniferous basin deposits. This terrane can be divided into three subzones on the basis of the 1gneous rocks present, metamorphte grade, and style of deformation. The metamorphism generally is no higher than the greenschist facies in the Boston area, but reaches the amphibolite facies to the south and west. The metamorphism is generally assigned an Alleghanian age although there is evidence for Late Precambrian deformation and metamorphism.
\end{abstract}

To the west, across the Bloody Bluff fault zone is the Nashoba Block, a terrane 1argely underlain by mafic volcanic rocks and volcanogentc sedimentary rocks. During the Ordovician-Silurlan this terrane underwent upper amphibolite facles metamorphism and was intruded by calc-alkaline intermediate plutons and metaluminous to peraluminous granites.

West of the Nashoba Block, across the Clinton-Newbury fault zone, is the Merrimack Trough, underlain by a thick sequence of flysch and calcareous flysch. Crosscutting Ordovician plutons establish an upper age limit for these sedimentary rocks and the ages of deformation and metamorphism.

Because of differing Late Proterozoic - Early Paleozoic histories, it is unlikely that the Boston-Avalon Zone and Nashoba Block could have been juxtaposed prior to the Mid-Paleozolc. Whether the Nashoba Block and Merrimack Trough represent separate terranes, a composite terrane jotned in the Late Precambrian or Early to Mid-Paleozoic, or faulted portions of a single terrane remains to be determined.

Aux alentours de Boston, au Massachusetts, la marge orientale de 1'Orogene Appalachlen comprend tro1s lanières majeures bordees par des failles. Chacune a son histolre geologique distincte. La plus orientale de celles-ci, la Zone de Boston-Avalon, possede des traits communs aux Ianières avaloniennes du Nord-Est des Appalaches... Parmi ceuxc1, on peut mentionner de volumineux plutons calco-alcalins, granitiques à dioritiques, tardiprotêrozoiques (650-600 Ma) ainsi que des volcanites, apparentées a ces derniers, qui sont associées avec la "phase principale" de 1'activite thermique avalonienne. En général, le metamorphisme ne dépasse pas le faciès à schistes verts dans la région de Boston quoiqu'11 attelgne le faciès à amphibolites au sud et à 1'ovest. On attribue genéralement un âge alléghanien au metamorphisme bien qu'il $\mathrm{g}$ ait preuve d'une deformation et d'un métamorphisme tardipreccambriens.

A l'ouest, de l'autre côté de la Zone de fallies de Bloody Bluff, se trouve le Bloc de Nashoba, une lanière formée surtout de volcanites mafiques et de roches sédimentaires volcanogenes. Durant 1'ordovicien et le Silurien, cette laniere subit un metamorphisme au facies a amphibolites superleur ainsi qu'une intrusion de plutons neutres calcoalcalins et de granites métalunineux à peralumineux.

A l'ouest du Bloc de Nashoba, au-dela de la zone de fallies de Clinton-Newbury. se trouve la Fosse de Merrimac qu1 renferme une puissante assise de flyschs et de flyschs calcaires. On établit. la limite supérleure sur 1 'age de ces roches sédimentaires ainsi que les âges de la deformation et du métamorphisme grâce aux plutons ordoviciens qui traversent celles-ci.

La fuxtaposition de la Zone de Boston-Avalon et du Bloc de Nashoba avant le Paléozoïque moyen $n$ 'est guère vraisemblable en ratson de leurs histoires différentes du Tardiprotérozoïque a 1'Eopaleozolque. II reste encore a determiner si le Bloc de Nashoba et la Fosse de Merrimac représentent des lantères séparées, une lanière composite assemblée lors du Tardiprecambrien ou de 1, Bo- au Medłopalézoíque, ou bien des parties d'une seule et même lanière qui sont en rapport par failles.

[Traduit par le journa1]

\section{INTRODUCTION}

The eastern margin of the Appalachian orogen in southeastern New England, east of the SiluroDevonian rocks in the Kearsarge - Central Maine Synclinorium (Lyons et al.. 1982), can be divided into three fault-bounded tectonic terranes (Fig. 1) identified from east to west as the Boston-Avalon Zone, the Nashoba Block or Zone and the Merrimack Trough. As the name suggests, the easternmost of these has been correlated with other fragments of Avalonia around the Atlantic (e.g., Williams and Max, 1980; Rast and Skehan, 1983; O'Brien et al. 1983). The relation of the Nashoba Block and 


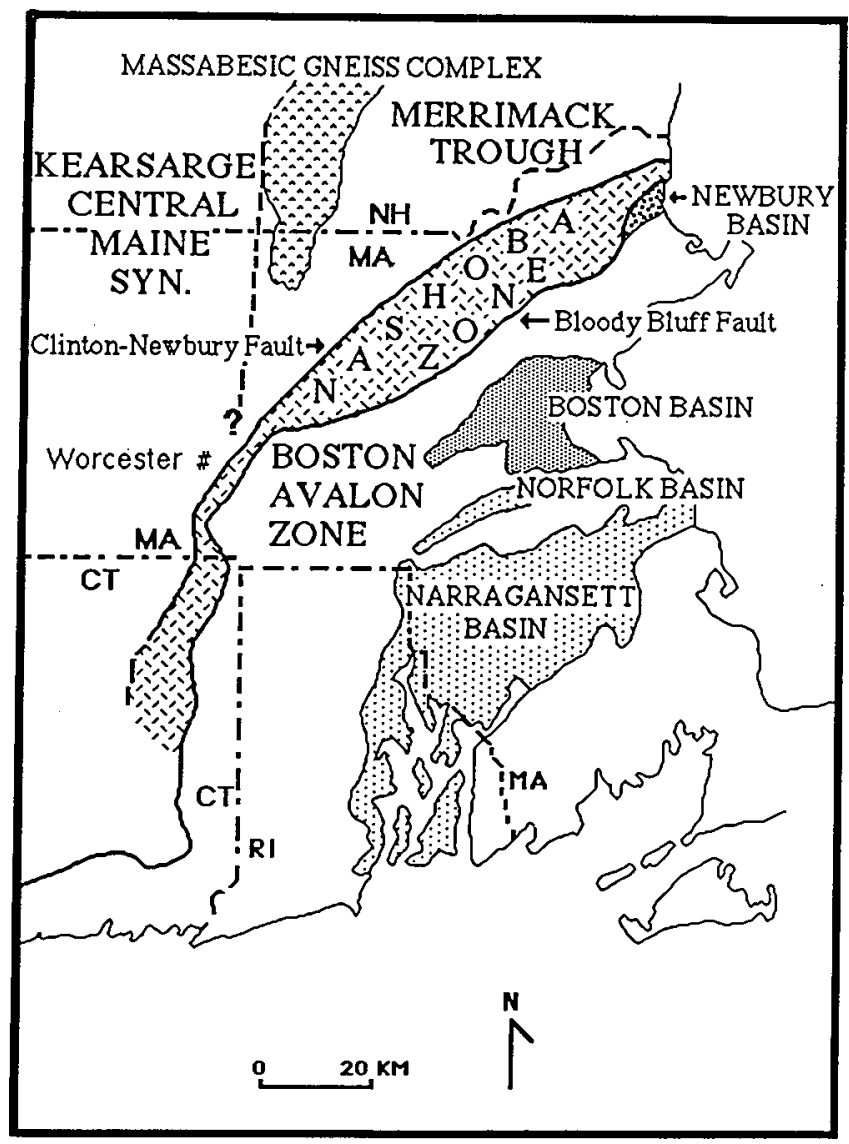

Fig. 1. Location map showing terranes of southeastern New England as used in this paper: Boston-Avalon Zone, Nashoba Block or Zone, Merrimack Trough, and Kearsarge-Central Maine Synclinorium. Sedimentary basins of the Boston-Avalon Zone include the Boston Basin (Late Proterozolc - Ear1y Paleozolc), and the Norfolk and Narragansett Basins (Carbontferous).

Merrimack Trough to Avalonia, however, is more problematic. In this paper, we discuss the geologic features that distinguish the BostonAvalon Zone and the Nashoba Block in the vicinity of Boston, Massachusetts. A summary of the salient features of the Merrimack Trough has been described recently by Lyons et al. (1982) and we present here on1y a short summary of this terrane.

\section{BOSTON-AVALON ZONE}

Late Proterozoic igneous rocks $(650-600 \mathrm{Ma})$ are area11y the most important feature observed at current levels of erosion in the Boston-Avalon Zone in eastern Massachusetts (Fig. 2) and represent the main phase of Avalonian thermal activity. The geological record prior to this igneous activity is scanty, but blocks and roof pendants within the plutonic rocks record bimodal volcanism and quartzrich sedimentation. Following the main phase of Avalonian igneous activity, magmatism ceased rather abruptly and the area became a stable shelf in the Early Paleozoic.

It is possible to subdivide the geology of the Boston-Avalon Zone into three fault-bounded subdivisions (inset, Fig. 2), which we refer to as Subzones 1, 2, and 3. Each subzone reflects a different character of the igneous rocks present, the degree of metamorphism, or the intensity and style of deformation. Subzones similar to ours were also noted by Zen (1983a), on the tectonic map that accompanied the Massachusetts state geologic map. While there may be disagreement over the boundaries of these subdivisions, there are significant differences in the geology between the subzones that are worth highlighting. The significance of these subdivisions is, however, not yet fully understood. They may simply represent fragments of a single terrane, reshuffled by faulting, or they may indicate that portions of the Boston-Avalon Zone had separate origins and thus that this zone is itself a composite terrane. The idea that Avalonia possibly represents a composite terrane has been expressed by many authors (e.g. , Williams and Hatcher, 1982, 1983; Zen, 1983b; Rast and Skehan, 1983; Keppie, 1985).

\section{Subzone 1}

Subzone 1 contains relatively few of the mafic igneous rocks that typify Subzone 2, and it lacks the intensely deformed granitic gneisses which are common in Subzone 3 . We further distinguish three distinct regions within this Subzone: $1 \mathrm{~A}, 1 \mathrm{~B}$, and 1C (Fig. 2). Subzones $1 \mathrm{~A}$ and $1 \mathrm{C}$ are underlain principally by Late Proterozoic plutonic rocks (Dedham and Westwood Granites) and coeval volcanic rocks (Lynn and Mattapan Volcanics) associated with the main Avalonian magmatic phase. Subzone 1B includes the Late Proterozolc sedimentary and volcanic rocks of the Boston Basin ( $\mathrm{F} 1 \mathrm{~g}$. 3). A11 of the geologic elements that have been used to correlate the Boston-Avalon Zone with other Avalonian terranes are located within Subzone 1.

The Dedham Granite and contemporaneous pyroclastic rhyolite-dacite of the Lynn and Mattapan Volcanics are the chief products of the main phase of Avalonian magmatic activity (650-600 $\mathrm{Ma}$ ) In Subzone 1 (Kaye and Zartman, 1980; Smith and Hon, 1984; Zartman and Naylor, 1984; Hon et al., 1984; Thompson, 1985). North of Boston, the Dedham is a fine- to coarse-grained hornblende- and blotite-bearing calc-alkaline intrusion, ranging from tonalite to granite in composition, with 57 $72 \% \mathrm{SiO}_{2}$ (Smith and Hon, 1984). The Lynn Volcanics are cogenetic with the Dedham: complete textural gradations occur between the two units as well as complete overlap in major and trace element abundances and $\mathrm{Nd}$ isotope ratios (Smith and Hon, 1984). Similar gradational textural relations have been reported between the Dedham and portions of the Mattapan Volcanics south of Boston (Kaye and Zartman, 1980).

While the main phase of Avalonian magmatic activity was calc-alkaline, that which preceded it was of a more alkaline nature (Smith and Hon, 1984). The Middlesex Fells Volcanics occur as blocks and pendants in the Dedham Granite north of Boston (Be11 and A1vord, 1976). They are bimoda1 and include both felsites and transitional alkali olivine basalts (Smith and Hon, 1984). The Middlesex Fe11s Volcanics have not been radiometrically dated, hence we cannot be sure by how much they preceded the main phase of Avalonian magmatism.

The oldest stratified rocks that occur as inclusions in the Dedham Granite are quartz-rich sedimentary rocks of the Westboro Formation (Be11 


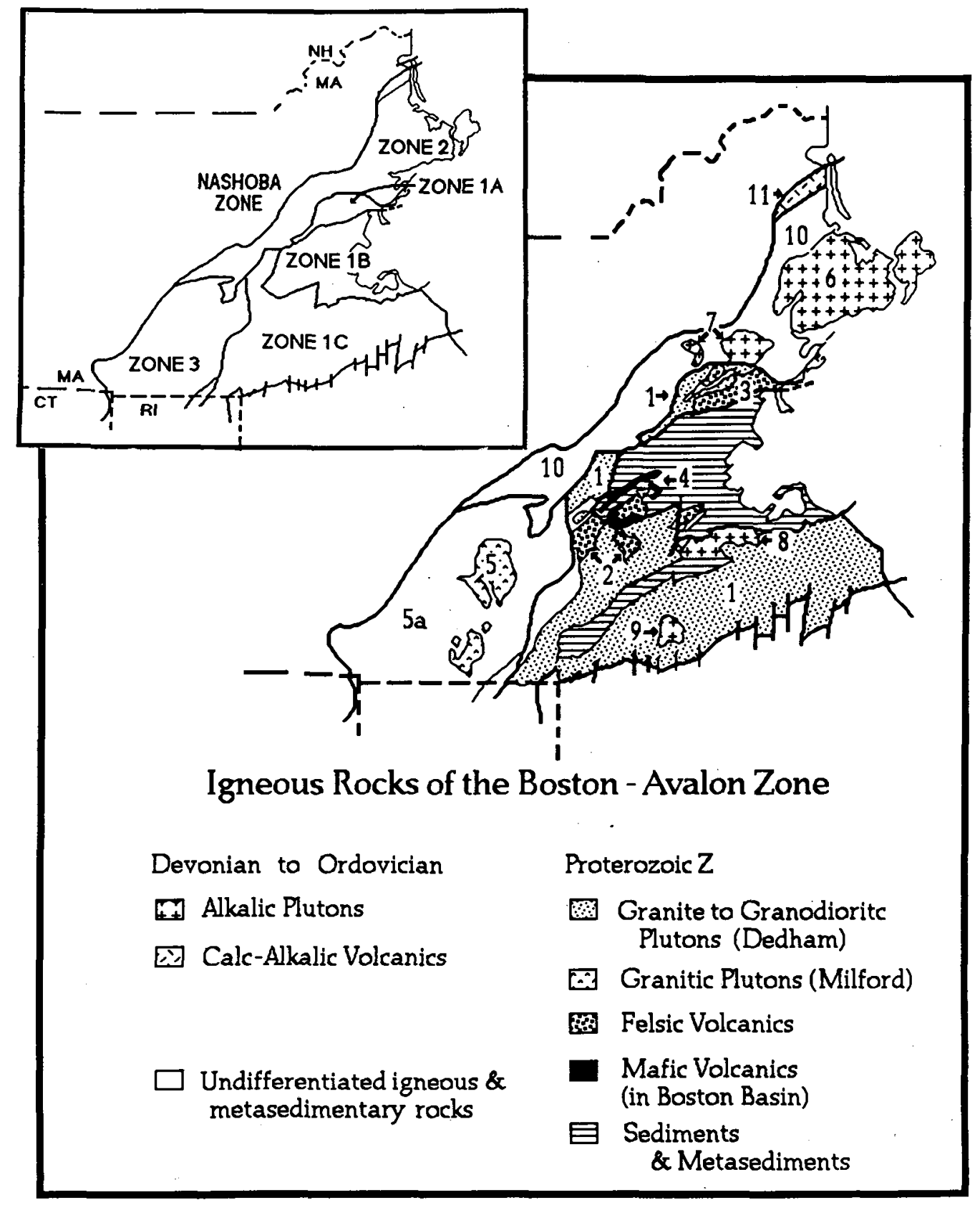

F1g. 2. Generalized geologic map of the major Igneous rocks of the Boston-Avalon Zone and fault sliver containing the Newbury Volcanies (modified after Zen. 1983a). Numbered units are: 1. Dedham Granite; 2. Mattapan Volcanics; 3. Lynn Volcanics; 4. Brighton Volcanics; 5. Milford Granite; $5 \mathrm{a}$. Leucocratic granitic gnelsses, Late Precambrian; 6. Cape Ann Grandte; 7 . Peabody Granite; 8. Quincy Granite; 9. Rattlesnake Hill P1uton; 10. Mafic plutonic and volcanic rocks; 11. Newbury Volcanics. Inset: Subzones of the Boston-Avalon Zone; see text.

and Alvord, 1976; Bailey, 1984). Bailey (1984) and Bailey et al. (1987) suggested that the Westboro formed as olistostromal deposits on a lower slope or upper submarine fan by the rifting and collapse of a craton margin. Similar rocks that may correlate with the Westboro Formation occur in the "Avalonian Zone" in Rhode Island in the Blackstone Group and possibly also in the Newport Formation (Be11 and Alvord, 1976; Bailey, 1984; Skehan et al., 1985; Bailey et al.,. 1987). Older plutonic rocks have been recognized as xenoliths in the Dedham granite as we11 (Smith and Hon, 1984).
The geologic record following the peak of Avalonian magmatic activity is preserved either within structural basins (Boston Basin) or as a thin veneer of sedimentary rocks locally overiying the magmatic rocks. Sedimentary rocks in the Boston Basin (Boston Bay Group) are largely conglomerates and shales that have been dated as Late Proterozoic on the basis of acritarchs (Lenk et al. 1982). Included within the Boston Bay Group is the Squantum Tillite or Tilloid (see Rehmer and Roy, 1976; and Rehmer, 1980 for discussion) and thin volcanic flows and 


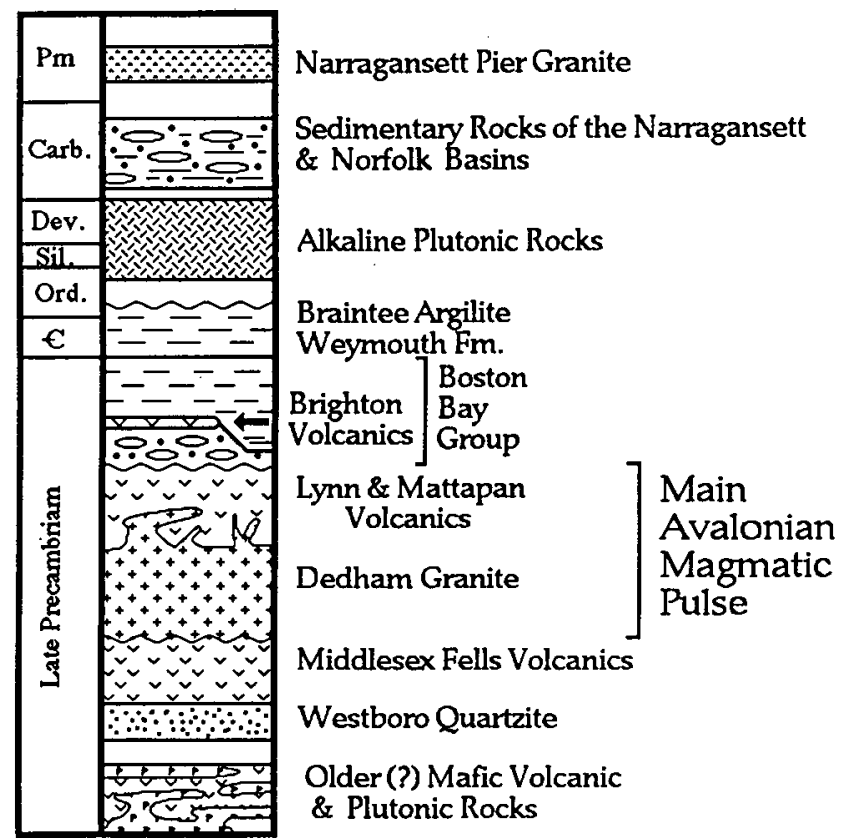

Fig. 3. Simplified stratigraphic column for Subzones 1 and 2 of the Boston-Avalon Zone, eastern Massachusetts. Narragansett Pler Granite from southern Rhode Island is projected onto the colum for completeness.

agglomerates of the Brighton Volcanics. These basaltic to intermediate volcanic rocks represent the last eplsode of Precambrian (Avalonian) magmatism in the Boston area (Durfee Cardoza et al., 1987). Subsequent1y, the Boston area became a stable she1f for the next $100-150 \mathrm{Ma}$ with no recorded magmatic activity. Cambrian platformal sedimentary rocks contain an Acado-Baltic trilobite fauna and allow the correlation of this area with other fragments of Avalonia (e.g., Rast and Skehan, 1983).

When magmatism resumed in the Early to Middle Paleozolc, a distinctly different suite of magmas was present than in the Late Proterozolc, indicating a changed tectonic environment. From the Late Ordovician through the Devonian, sporadic peralkaline plutonism and local felsic volcanism occurred within this terrane in Massachusetts and Rhode Island (Zartman and Marvin, 1971; Naylor and Sayer, 1976; Zartman, 1977; Zartman and Naylor, 1984; Hermes and Zartman, 1985). The peralkaline intrusions are largely grantic but include some gabbro. Rocks of similar alkaline compositions have been interpreted as forming in anorogenic settings (Pitcher, 1982). The development of an early Paleozolc stable cratonal shelf and the lack of evidence for Ordovician-Devonian deformation throughout the Boston-Avalon Zone are consistent with this interpretation.

Finally, Carboniferous fluviatile rocks in the Norfolk and Narragansett Basins record the youngest Paleozoic sedimentary history in the Boston-Avalon Zone and serve as important guides for differentiating Alleghanian metamorphic and structural events. In southernmost Rhode Island, the peraluminous Narragansett Pier Granite (272 Ma, Hermes et al. 1981) closes out the Paleozolc magmatic history of this terrane.
Subzone 2

Subzone 2 of the Boston-Avalon Zone (inset, Fig. 2) occurs to the northwest, between Subzone 1 and the Bloody Bluff Fault Zone. It is underlain largely by a complex of mafic plutonic and volcanic rocks (Be11 and Alvord, 1976; Hurley and Shearer, 1981; units "Zv" and "Zdigb" of Zen, 1983a) that are generally more highly deformed than those in Subzone 1, particularly as the Bloody Bluff Fault is approached. Field evidence indicates that the majority of these mafic rocks 11 kely predate the main phase of Avalonian magmatism, since some have been intruded by granites believed related to the Dedham or Milford (Barosh et al., 1977; Hepburn and DiNitto, 1978). However, younger gabbros and other rocks related to the peralkaline Ordovician to Devonian period of intrusion also are present in this zone, especially toward the northeast near the Cape Ann Complex (Fig. 2)

Whether the Precambrian mafic igneous rocks in Subzone 2 are approximate1y contemporaneous with the main phase of Avalonian magmatism in Subzone 1 is unclear. $\mathrm{Rb}-\mathrm{Sr}$ and $\mathrm{K}-\mathrm{Ar}$ 1sotopic systems generally have been disturbed by younger events (Zartman et al., 1970; Schutts et al., 1976; Hurley and Shearer, 1981; Zartman and Naylor, 1984). Zartman and Naylor (1984) reported a single K-Ar date of $886 \pm 22 \mathrm{Ma}$ on a hornblende from a gabbroic pegmatite in this zone. However, because they were unable to rule out the possibility of excess radiogenic argon in this sample, the significance of the age remains uncertain.

\section{Subzone 3}

Subzone 3 is separated everywhere by faults from Subzones 1 and 2, and is characterized by Late Proterozoic leucocratic granitic gneisses and a generally higher metamorphic grade (amphibolite facies) than is found in Subzones 1 and 2. Ductile deformation is common, particularly near the borders of this subzone where foliation is more intense, especially near the Bloody Bluff Fau1t Zone. Locally, metasedimentary and metavolcanic rocks are present in Subzone 3 (Zen, 1983a). The Milford Granite $(630 \pm 15 \mathrm{Ma})$ intrudes the gneissic units near the center of this subzone (Zartman and Naylor, 1984) (Fig. 2) and includes both a granitic and a granodioritic phase (Zen, 1983a; Sheridan et al.. 1987). Both these phases are largely unfoliated and have escaped most of the later deformation which affected this subzone. The granitic phase is characteristically a salmon-pink biotite granite with garnet as a common accessory. While there is an overlap in the ranges of most major element concentrations between the Milford Granite and the Dedham Granite of Subzone 1, on average the Milford is slightly more aluminous. Garnet is common in the Milford Granite whereas garnet is absent from the Dedham Granite (Sheridan et al.. 1987). Some of the granitic gneisses of Subzone 3 are also garnet-bearing, particulary the Hope Valley Alaskite. The relationshlp of the more gnelssic units with the Milford Grantte is not yet well understood. Recently 0'Hara and Gromet (1985) have argued that at least some of these gneisses belong to a separate Late Precambrian Avalonian terrane (their Hope Valley terrane). 
Metamorphism and Deformation of the Boston-Avalon Zone

In the Boston area, most of the Boston-Avalon Zone (Subzones 1 and 2) has been metamorphosed no higher than the lower greenschist facies, with brittle faulting being the most common type of deformation observed (Zen, 1983a). Late Proterozoic and Early Paleozolc sedimentary rocks in the Boston area have open folds (Billings, 1976), with the development of cleavage in the more argillaceous rocks. Metamorphism increases to the amphibolite facies to the south and west of the Boston area in Subzones 2 and 3, where deformation and ductile shearing are more intense.

The Carboniferous sedimentary rocks of the Norfolk and Narragansett Basins south of Boston have been metamorphosed during the Alleghanian Orogeny with the grade of metamorphism increasing to the south (Hepburn and Rehmer, 1981). Temperatures exceeded $600^{\circ} \mathrm{C}$ in a Barrovian-type sequence in southern Rhode Island (Grew and Day, 1972). Based on this regional evidence, the metamorphism of Subzone 1 is 1arge1y ascribed to the Alleghanian. Evidence for Alleghanian metamorphism has been presented by 0'Hara and Gromet (1983) for high-grade metamorphism along the Honey Hill fault in Connecticut and by Dallmeyer (1982) for gneisses in swuthern Rhode Island, 11ke1y correlative with those in Subzone 3. This supports, but does not prove, the 1dea that the higher grades of metamorphism and ductile deformation in our Subzones 2 and 3 are also likely, at least in part, Alleghanian in age. Zartman et al. (1970) described disturbed K-Ar ages over a widespread area of eastern New England. including the Boston-Avalon Zone, which they attributed to a regional Alleghanian thermal event.

While it is well established that the BostonAvalon Zone experienced Alleghanian metamorphism and deformation, detalls of prior events are not as we11 understood. During the Early to MidPaleozoic, contact metamorphsim occurred adjacent to the Ordovician-Devonian peralkaline plutons. Schutts et al. (1976) reported a thermal and metasomatic event at about $370 \mathrm{Ma}$ which affected some whole rock and mineral $\mathrm{Rb}-\mathrm{Sr}$ ages and $\mathrm{K}$-Ar mineral ages in the area of our Subzone 2. They interpreted this event as being caused by hydrothermal activity associated with intrusion of the peralkaline plutons in this area. (Below, we suggest that this event might mark the time of juxtaposition of the Boston-Avalon Zone and the Nashoba Block.)

The Boston-Avalon Zone in Massachusetts a1so experienced a Precambrian deformation. Sedimentary xenoliths enclosed in the $630 \mathrm{Ma}$ Dedham Granite north of Boston are folded. However, definitive evidence for a Precambrian metamorphism has not been found in the Boston area. In Rhode Island, Precambrian sedimentary and volcanic rocks experienced deformation and lower greenschist facies metamorphism prior to the intrusion of a 595 Ma granite (Rast and Skehan, 1981, 1983; Skehan and Rast, 1983). Dreler (1983) described evidence for Precambrian low-grade metamorphism of the Blackstone Serles in Rhode Island. Thus, it is $11 k e 1 y$ that the Boston area also experienced a similar low grade metamorphism prior to the main phase of Avalonian magmatism.
NASHOBA BLOCK

Northwest of the Boston-Avalon Zone, across the prominent Bloody Bluff Fault is the Nashoba Block, a distinct1y different terrane (Fig. 1). A thick pile of mafic volcanic rocks and volcanogenic sedimentary rocks of Ordovician or older age, now metamorphosed and migmatized under upper amphibolite facies conditions to amphibolite, biotite gneiss and schist, underlies this terrane. Peraluminous granite and contemporaneous Ordovician-Silurian calc-alkaline plutons of intermediate composition ( $\mathrm{Fig} .4$ ) are also of major importance in the development of the Nashoba Block.

The oldest rock unit yet dated in this terrane is the leucocratic Fish Brook Gneiss, which 01szewski (1980) determined to be $730 \mathrm{Ma}$ based on $\mathrm{U} / \mathrm{Pb}$ studies of zircons with volcanic morphology. However, the contact relationships between the Fish Brook Gneiss where dated and other units in the Nashoba Block are not firmly established. The distinctive "swirled follation" of parts of the Fish Brook Gneiss (Be11 and Alvord, 1976) suggests that the F1sh Brook may be more highly deformed than other rocks in this terrane, possibly indicating a period of deformation and metamorphism (Late Precambrian?) prior to deposition of the other units.

Mafic volcanic rocks (Marlboro Formation) and volcanogenic sedimentary rocks with minor carbonates (Nashoba Formation) were deposited in the Nashoba Block prior to the intrusion of the Andover Granite. Direct dating of the Marlboro amphibolites has been unsuccessful. However, $\mathrm{Nd}$ model ages calculated against typical depleted mantle mode1 sources suggest a pre $-450 \mathrm{Ma}$ age for these rocks (DiN1tto et al.. 1984). The Marlboro volcanics are basalts including some high alumina types, with trace element signatures (10 $\mathrm{Ta}$ and $\mathrm{Nb}$ contents compared with Ce and Th - see DiNitto et al. 1984) most compatible with an arc or marginal basin tectonic setting.

The Nashoba Block experienced widespread plutonism from the mid-ordovician through the Silurian (approximately $450-400 \mathrm{Ma}$ ), with intrusion of peraluminous granites (Andover Granite; "Sgr" of Zen, 1983a; granitic phase of the Indian Head Hill Pluton) being broadly contemporaneous with that of calc-alkaline intermediate composition magmas (Sharpners Pond Diorite; dioritic phase of the Indian Head Hill Pluton; Assabet Quartz Diorite; Straw Hollow Diorite). The intermediate plutons are 1ittle deformed and range in composition from gabbrolc cumulates to hornblende- and biotite-bearing diorites and tonalites with sphene is a nearly ubiquitous accessory phase (Castle, 1964; H111 et al., 1984a,b; Hon et al., 1986). Zartman and Naylor (1984) determined a $430 \pm 5 \mathrm{Ma}$ age from zircon in the Sharpners Pond Diorite; H111 et al. (1984a) reported a $402 \pm 5 \mathrm{Ma} \mathrm{Rb}-\mathrm{Sr}$ whole rock age for the older, dioritic phase of the Indian Head Hill Pluton, which is cut by the younger granitic phase. Hill et al. (1984a,b) noted the similarity of rare earth and other trace element distributions between the calc-alkaline plutons of the Nashoba Block and plutons of similar mineralogy developed at convergent plate boundaries (e.g., Sierra Nevada batholith, Noyes et al., $1983 a, b)$.

Peraluminous granitic intrusions in the Nashoba 
Block are more extensive than the intermediate plutons, particularly towards the northeast (Fig. 4). Many of these intrusions have been grouped together into the Andover Granite, although it has long been recognized that the Andover includes a number of different varieties of granite, some follated and some not (Castle, 1964; Zartman and Naylor, 1984). Hill et al. (1984a) suggested that the Andover could be subdivided into at least two major units: a more foliated, biotite- and muscovite granite having a moderately steep rare earth element pattern; and a less follated, biotite-poor, muscovite-rich and garnet-bearing granite having quite flat rare earth element patterns. More detailed mapping and analytical studies are in progress on the Andover. The Andover Granite has yet to be dated satisfactorily. Zartman and Naylor (1984) reported $\mathrm{Rb}-\mathrm{Sr}$ whole rock data that indicated an age of $446 \pm 32 \mathrm{Ma}$ (without aplites) or $408 \pm 22 \mathrm{Ma}$ (including aplites, associated with the pegmatitic phase). Handford (1965) reported a $\mathrm{Rb}-\mathrm{Sr}$ whole rock age of $450 \pm 22$ $\mathrm{Ma}$ for the Andover Granite.

If the ca. $450 \mathrm{Ma}$ "ages" for the Andover Granite are approximately correct, then granitic plutonism in the Nashoba Block spanned some $50 \mathrm{Ma}$. There is ample evidence for the coexistance of granitic and intermediate to mafic magmas in the Sharpners Pond Diorite and within the un-named "Sgr" intrusive unit of Zen (1983a) (magmatic pillows, gradational contacts, etc.; Castle, 1964; Hon et al., 1986) and it is likely that both granite and diorite were intruded in several pulses. Trace element and isotope chemistry indicates that the granites are not fractionates of the calc-alkalic magmas, but resulted from anatexis of a crustal source (Hi11, 1985; Hon et al., 1986).
Metamorphism and Deformation

The sedimentary and volcanic rocks in the Nashoba Block have been polydeformed and polymetamorphosed to the sillimanite and second silimanite zones in an andalusite-sillimanite facies series. Temperatures in the western Nashoba Block exceeded $600^{\circ} \mathrm{C}$. (Abu-moustafa and Skehan, 1976; Hepburn and Munn, 1984) and migmatites are common in the Nashoba Formation. Zones of ductile shearing and mylonitization are also widely developed associated with the numerous faults within this terrane. These generally have been mapped and interpreted as thrust faults (Skehan, 1968; Be11 and Alvord, 1976. Skehan and Abu-moustafa, 1976; Barosh et al., 1977; Hepburn and Munn, 1984).

The age of metamorphism and deformation in the Nashoba Block is generally thought to be Ordovician to Silurian by comparison with dated igneous rocks (Ha11 and Robinson, 1982; Robinson, 1983; Hepburn and Munn, 1984; Zartman and Naylor, 1984). The Sharpners Pond Diorite is the key to this interpretation as it is essentially unaltered and undeformed and its age of $430 \mathrm{Ma}$ is thought to establish the minimum time for the principal deformation and metamorphism. As noted above, the Andover Granite contains both foliated and unfoliated varleties and may therefore overlap the end of the deformation. Its metaluminous to peraluminous nature suggests that it formed by anatexis of a sedimentary source. The association of pegmatitic phases of the Andover with the Nashoba Formation has long been recognized and migmatites within the Nashoba generally increase as the Andover is approached. Castle and Theodore (1972) estimated P-T conditions for a pegmatitic phase of the Andover as $650^{\circ} \mathrm{C}$ at $5 \mathrm{~kb}$, close to the

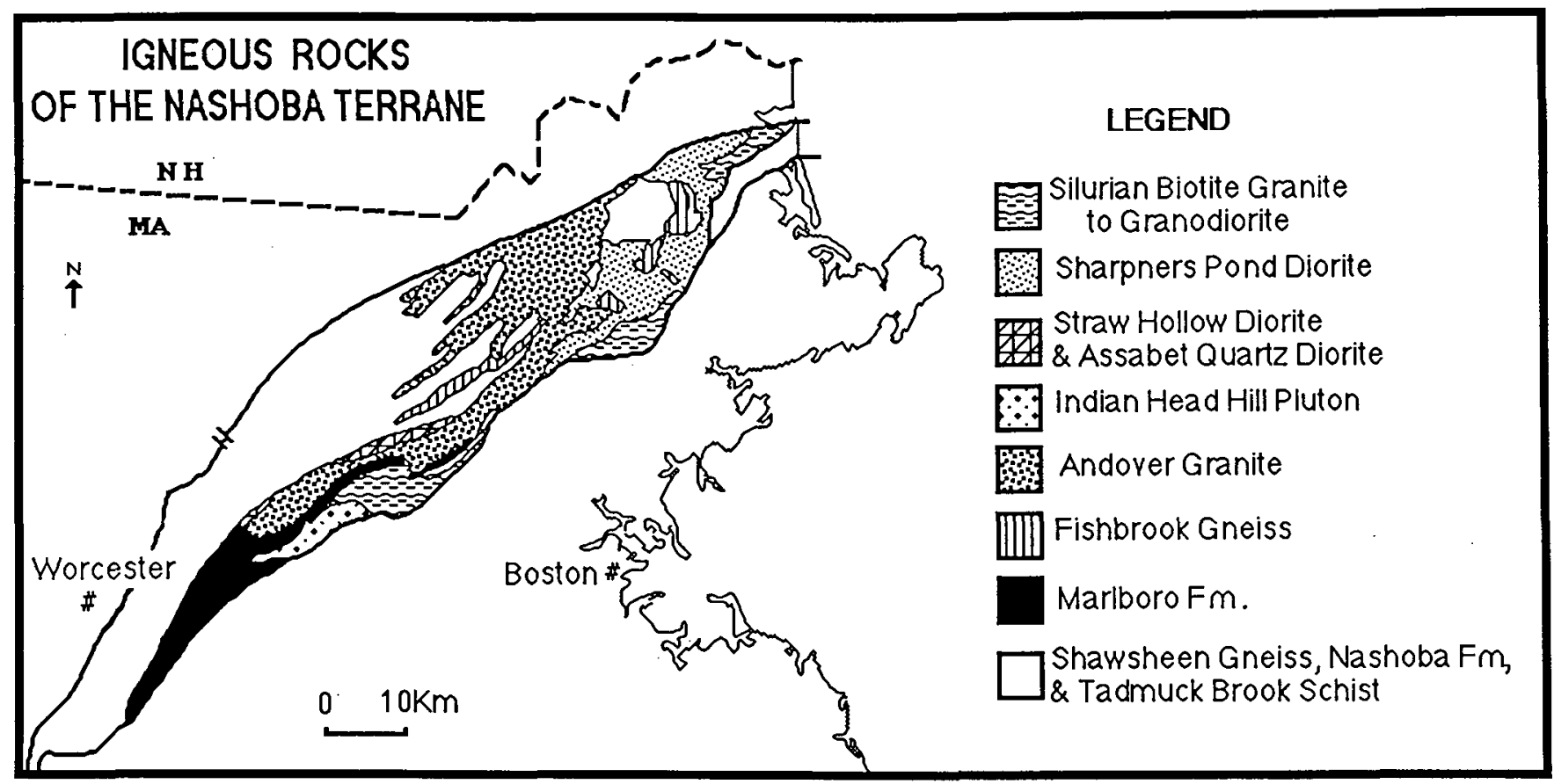

F1g. 4. Igneous rocks of the Nashoba B1ock or Terrane, eastern Massachusetts. 
temperature estimates for metamorphism in the Nashoba. Thus, it seems 1ikely that at least portions of the Andover were produced by anatexis of Nashoba rocks during the peak of metamorphism and that the metamorphism occurred in the range of 450$430 \mathrm{Ma}$, if the $450 \mathrm{Ma}$ date on the Andover is correct. However, the date of $408 \pm 22 \mathrm{Ma}$ that is largely influenced by the aplitic phases associated with the Andover pegmatites (Zartman and Naylor, 1984) may indicate a somewhat younger minimum age for the metamorphism. Possible further support for an Ordovician age for the metamorphsim comes from 01szewsk1's (1980) Rb-Sr whole rock analyses of a number of metasedimentary and metavolcanic rocks from the Nashoba Block and surrounding areas which, a1though somewhat scattered, indicated a period of isotopic resetting and metamorphism at about 450 $\mathrm{Ma}$.

Isotopic systems in the Nashoba Block alşg record evidence of younger closing times. ${ }^{40} \mathrm{Ar} /{ }^{39} \mathrm{Ar}$ ages for hornblende from amphibolites in the Marlboro and Nashoba Formations give Mississippian cooling ages ranging from $354-325 \mathrm{Ma}$, and $\mathrm{Sm}-\mathrm{Nd}$ and $\mathrm{Rb}-\mathrm{Sr}$ mineral isochrons from the Straw Hollow Diorite record cooling ages between 342-299 Ma (Hepburn et a ., 1987). Zartman et al. (1970) indicated that $\mathrm{K}$-Ar ages on micas reflect Permian cooling or disturbance.

\section{Newbury Volcanic Complex}

The Newbury Volcanic Complex occurs in a sma11 fault-bounded sliver between the Boston-Avalon Zone and the Nashoba Block (Fig. 1 and Fig. 2, \#11). These rocks are essentially unmetamorphosed basaltic, andesitic and rhyolitic volcanics with interbedded sedimentary rocks containing Silurian to Ear1y Devonian fossils (Shride, 1976). Citing geochemical evidence, Hon and Thirlwall (1985) suggested the Newbury Volcanics formed in a subduction zone environment. Volcanic rocks similar in both composition and age to the Newbury are found in the coastal volcanic belt in Malne (Gates and Moench, 1981).

\section{MERRIMACK TROUGH}

Northwest of the Nashoba Block (Fig. 1), across the C1inton-Newbury fault zone, is another potential terrane, the Merrimack Trough, with different geological characteristics (Lyons et al., 1982; 01szewsk1 et al.. 1984). The rocks of the Merrimack Trough previously were thought to be Siluro-Devonian (see Lyons et al., 1982) and were included in the regionally extensive Merrimack Synclinorlum. However, recent dating of crosscutting plutons (Gaudette et al., 1984; Zartman and Naylor, 1984; Hon et al., 1986) indicates that the sedimentary rocks of the Merrimack Trough are preMiddle Ordovician. The exact boundary of this terrane on the north and west is not yet clearly differentiated, particularly in Massachusetts, because of uncertainties in the age and correlation of varlous metasedimentary units. Lyons et al. (1982) have shown that the Massabesic Gneiss Complex of southern New Hampshire and north-central Massachusetts (Fig. 1) is associated with the Merrimack Trough and 01szewsk1 et al. (1984) included it as part of this terrane. This complex contains two ages of orthognelss and o1der paragneiss; the orthogneisses have been dated as $650 \mathrm{Ma}$ and $.475 \mathrm{Ma}$ (Besancon et al.. 1977; Aleinikoff et al., 1979; Kelly et al., 1980).

The Merrimack Trough is underlain large1y by the Merrimack Group of metasedimentary rocks, a thick sequence of flysch and calcareous flysch. These rocks are polymetamorphosed and deformed. The grade of metamorphism genera11y increases westward, from the greenschist facies along the ClintonNewbury fault zone in the east, to the sillimanite and second sillimanite zones adjacent to the Massabesic Gneiss in the west (Bothner et al., 1984). The metasedimentary rocks of the Merrimack Group are cut by the Newburyport Quartz Diorite (450 Ma, Zartman and Naylor, 1984) and the Exeter Diorite ( $473 \mathrm{Ma}$, Gaudette et al., 1984; Hon et al., 1986), hence the Merrimack Group is pre-Middle Ordovician in age. Bothner et al. (1984) suggested that the paragneiss in the Massabesic Gneiss Complex that is cut by the $650 \mathrm{Ma}$ old orthogneiss is a high-grade equivalent of the Berwick Formation, part of the Merrimack Group metasedimentary rocks. If this is correct, then the sedimentary rocks in the Merrimack Trough are Precambrian. As the Exeter Diorite is undeformed and cuts deformed and metamorphosed rocks and has a contact aureole developed adjacent to the pluton (Bothner et al., 1984; Hon et al., 1986), the metamorphism and deformation must also be preMiddle Ordovician.

\section{DISCUSSION}

\section{Boston-Avalon Zone}

Figure 5 summarizes the igneous, sedimentary, metamorphic and deformational histories of the Boston-Avalon Zone, the Nashoba Block, and the Merrimack Trough. The history for the BostonAvalon Zone represents that for Subzones 1 and 2 . Many authors have suggested that the Avalonian terrane is composite (e.g., Williams and Hatcher, 1982, 1983; Zen, 1983b; Rast and Skehan, 1983; Keppie, 1985) and was assembled during the Late Precambrian (Williams and Hatcher, 1983; Keppie, 1985) prior to deposition of overlapping Cambrian strata. Differences between the subzones of the Boston-Avalon Zone in the Boston area are consistent with this interpretation, but proof of their separate evolution has not been established. Particularly noteworthy is the contrast between Subzone. 2, largely underlain by mafic rocks, and the more granitic Subzones 1 and 3 . If the subzones of the Boston-Avalon Zone did originate as separate terranes, it is 11 ke1y that they were joined by the Late Precambrian. Recognized Cambrian strata are restricted to Subzone 1; none overlaps onto Subzones 2 or 3 . However, if the abundant granitic dikes and stringers in portions of Subzone 2 are related to the Dedham Granite, they indicate 1ts proximity to the other subzones at the time of the $600 \mathrm{Ma}$ Avalonian magmatism. Be11 and Alvord (1976), however, noted the apparent lack of granitic dikes related to the Dedham Granite in the most northwesterly portions of what is our Subzone 2 .

Sedimentary and volcanic xenoliths and roof pendants (Westboro Formation, Middlesex Fells Volcantcs) in the calc-alkaline plutons of the Boston-Avalon Zone record events which pre-date the 


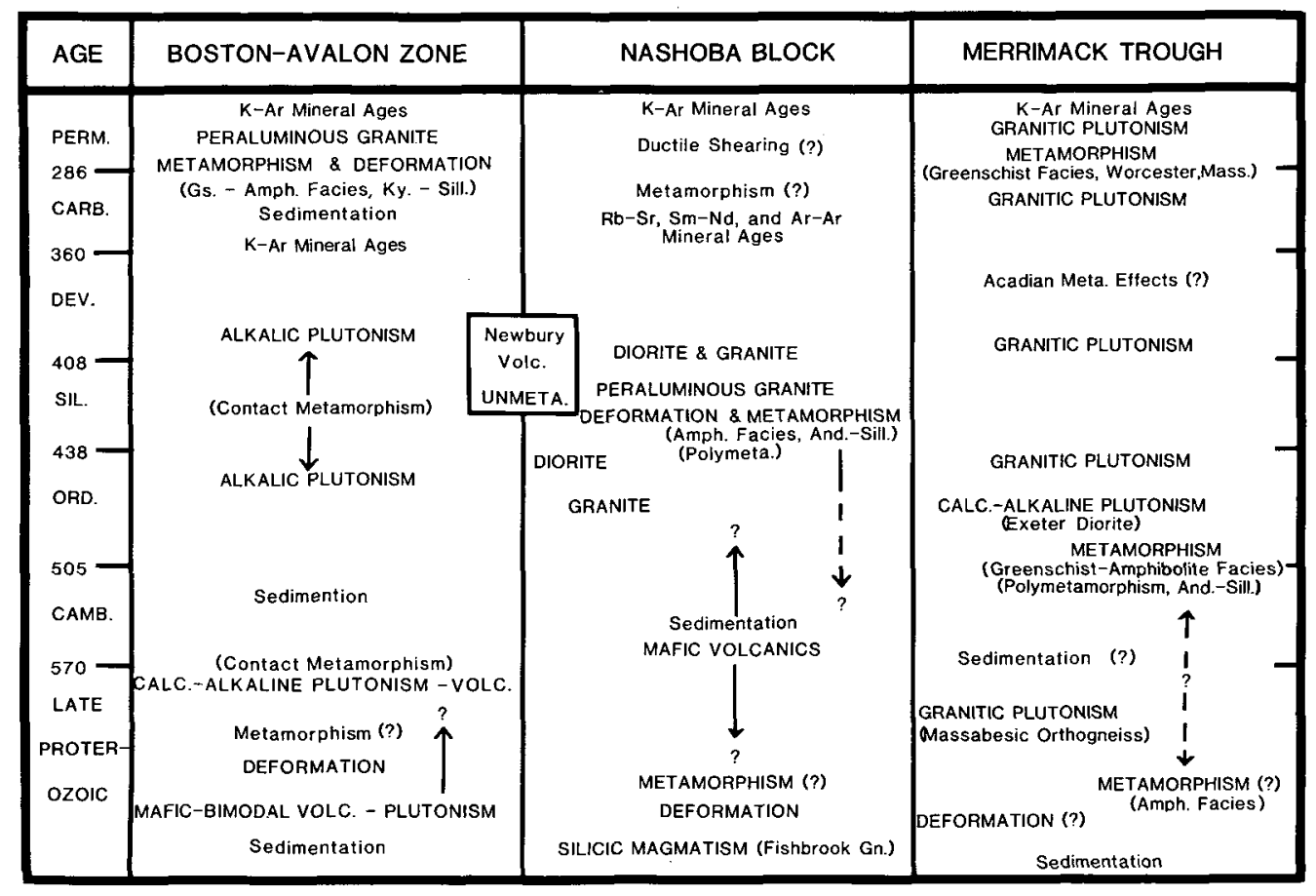

Fig. 5. Comparison of geologic events in the terranes in eastern Massachusetts and adjacent areas.

main phase of Avalonian magmatic activity. Evidence suggests that the Boston area was undergoing rifting or crustal extension prior to $650-600$ Ma. Bailey et al. (1987) summarized structural and sedimentologic evidence that the Westboro Formation, north of Boston (Fig. 3) and other premain phase sedimentary rocks were deposited in a cratonal rift environment. The Middlesex Fells Volcanics are bimodal and contain both rhyolites and alkali basalts (Smith and Hon, 1984). These features are also compatible with a rift environment. Furthermore, preliminary work on the abundant mafic igneous rocks of Subzone 2 indicates that at least some are alkaline (Sahagian and Hon, 1985). Present geochronological data are too sparse to permit accurate dating of this extensional event in the Boston area. A pre-700 Ma age would be indicated if these alkali basalts correlate with those in the basal part of the 760 $\mathrm{Ma}$ Burin Group in Newfoundland, which was deposited in an extensional environment (0'Brien et al., 1983) (see also, discussion in Bailey et al., 1987).

In the Boston-Avalon Zone, the rifting stage was followed by the voluminous calc-alkaline magmatism in the period 650-600 Ma. By itself, this observation is consistent with either of two tectonic environments. Modern calc-alkaline rocks of similar composition occur at continental margins above subduction zones (e.g., Sierra Nevada, Noyes et al., 1983a,b). Some modern continental rifts (e.g. . R1o Grande Rift, Gardner et al., 1986) also contain calc-alkaline suites similar to the DedhamLynn complex. Parenthetically, we note that the batholithic mass of the calc-alkaline Dedham-Lynn suite contrasts with the relatively low volume of exposed calc-alkaline rocks in the Rio Grande Rift, (Gardner et al., 1986).

While the Avalon Peninsula in Newfoundland experienced some calc-alkaline magmatism in this period (0'Brien et al., 1983), the volume of these magmas in the Boston-Avalon Zone appears to be much greater and is a distinctive feature of the Avalonian terrane in eastern Massachusetts. However, our results for the Boston-Avalon Zone are consistent with the general pattern of tectonism (rifting followed by convergence) proposed for Newfoundland by Strong et al. (1978) and by O'Brien et al. (1983) and for Avalon generally by Rast and Skehan (1983).

\section{Nashoba Block and Newbury Volcantes}

Metabasalts in the Marlboro Formation have trace element signatures of an are or marginal basin setting (DiNitto et al., 1984). It is interesting that the Chopawamsic Volcanics (Pav1ides, 1981) in Virginia occur in this same time interval and are compositionally similar to the Marlboro metavolcanic rocks. Williams and Hatcher (1983) placed the Chopawamsic Volcanics in a separate terrane to the west of the Avalon terrane, a tectonic position similar to that of the Nashoba Block. We suggest a posstble correlation between the Marlboro and Chopawamsic Volcanics.

Between $430 \mathrm{Ma}$ and $402 \mathrm{Ma}$ the deformed and metamorphosed metasediments and metavolcanics of the Nashoba Block were intruded by calc-alkaline intermediate magmas (Fig. 5). These intrusions overlap temporally with peraluminous to metaluminous granites of unrelated magmatic 1ineage. The calc-alkaline plutons 1ike1y represent subduction-related magmas (H111 et al., 1984a; Hon et al., 1986). When the age of the Andover Granite is resolved, it will be possible to better determine whether the calc-alkaline plutons acted as a thermal trigger to initiate melting of metasedimentary rocks in the Nashoba Block, or 
whether the granites formed in response to structural events (over-thrusting?), as in the case of the Manaslu Granite in the Himalaya (Le Fort, 1981).

The Newbury Volcanics (Fig. 5) are essentially contemporaneous with and are of similar composition to the intermediate and granitic plutons in the Nashoba Block (Hon and Thirlwall, 1985). Previous1y, the unmetamorphosed condition of the Newbury Volcanics led to the suggestion that they were related to the the Boston-Avalon Zone (Shride, 1976). Because of the similarities in age and chemistry between the Newbury and the plutons of the Nashoba Block, we argue that the Newbury Volcanics represent downfaulted remnants of cover once present above the Nashoba Block, an interpretation first suggested by $\mathrm{Ha} 11$ and Robinson (1982). If the interpretation of Hon and Thirlwa11 (1985) is correct, the Newbury Volcanics formed at a convergent plate boundary in the Silurian to Early Devonian. This implies subduction just prior to the Acadian Orogeny (Hon et al:, 1986). However, there is no evidence in the Newbury Volcanics for Acadian metamorphic or deformational effects.

\section{Timing of Tectonic Events}

Some constraints can be placed on the time of joining of the Nashoba Block and the Boston-Avalon Zone (see also discussion by Zartman and Naylor, 1984). Both terranes contain Late Proterozoic rocks: pre-630 Ma for the Boston-Avalon Zone (xenoliths and pendants in plutons) and dated 730 $\mathrm{Ma}$ gnelss in the Nashoba Block. However, the large-scale Late Proterozoic main phase Avalontan magmatism of the Boston-Avalon Zone is not found in the Nashoba Block. Similarly, between approximate1y 450-400 Ma, the Nashoba Block experienced intense regional metamorphism and deformation, as well as the emplacement of calcalkaline intermediate plutons and the extensive formation of migmatites and anatectic granite. None of this activity is found across the Bloody Bluff fault zone in the Boston-Avalon Zone. Instead, in this time interval the Boston-Avalon Zone was intruded by distinctiy different, peralkaline plutons, which in turn are absent from the Nashoba Block (Zartman and Naylor, 1984). Thus, the different Late Proterozolc and Ear1y Paleozolc histories of the two terranes make it difficult to assemble them in their current positions prior to the mid-Paleozoic. The ca. $370 \mathrm{Ma}$ $\mathrm{Rb}-\mathrm{Sr}$ ages from the Boston-Avalon Zone and the Mississipplan $40 \mathrm{Ar} /{ }^{39} \mathrm{Ar}$ cooling ages from the Nashoba Block (FIg. 5) may reflect the time of juxtaposition (collision-related uplift and unroofing) of these terranes.

A mid-Paleozoic time of accretion of the BostonAvalon Zone and the Nashoba Block is consistent with other evidence for the time of welding of Avalon to terranes to the west in the northern Appalachians (see more complete discussions : in Coleman-Sadd, 1980; Zen, 1983b; Williams and Hatcher, 1983; Keppie, 1985). This is exemplified by the Ackley City Granite (350-355 Ma, Bell et al.., 1977; Dallmeyer et al., 1980) which seals the Hermitage Bay fault along the boundary between the Avalon and Gander zones in eastern Newfoundland. On the other hand, O'Hara and Gromet (1983) pre- sented evidence that their Hope Valley Shear Zone is A1leghanian in age and suggested that this shear zone is continuous with the Bloody Bluff fault zone, implying that accretion of the Boston-Avalon Zone with North America took place in the Permian. To date, there is no direct evidence in the Boston area to differentlate between Mid-Paleozoic vs. Late Paleozoic emplacement of the Boston-Avalon Zone in the Boston area. However, the fact that metamorphic hornblendes from the Nashoba Block record pre-Alleghanian ${ }^{40} \mathrm{Ar} /{ }^{39} \mathrm{Ar}$ ages in the range 354-325 Ma (Hepburn et al., 1987) indicates that this terrane cooled through approximate $1 \mathrm{y} 480^{\circ} \mathrm{C}$ by this time. This is in marked contrast to southern Rhode Island and south-central Connecticut where Wintsch and Sutter (1986) reported $40 \mathrm{Ar} /{ }^{39} \mathrm{Ar}$ hornblende ages that are 75-100 Ma younger than the Nashoba cooling ages. Hence, any Alleghanian thermal effects within the Nashoba Block were insufficient to affect the Ar/Ar systematics, which is consistent with the interpretation of Wintsch and Sutter (1986) that Alleghanian effects diminish rapld1y to the north away from southern Rhode Island and Connecticut.

Both the Boston-Avalon Zone and the Nashoba Block have isotopic evidence for a crustal component marked1y older than any of the rocks now exposed at the surface. Olszewsk1 (1980) dated $1511 \mathrm{Ma}$ detrital zircons from the Westboro Formation, sedimentary rocks of the Boston-Avalon Zone which pre-date the main phase of Avalonian magmatism. $\mathrm{H} 111$ and Ross (1983) Indicated that granulite facies crustal xenoliths from a Mesozoic dike near Boston have $\mathrm{Nd}$ mode1 ages in excess of $800 \mathrm{Ma}$. In the Nashoba Block, 01szewski (1980) also identified detrital zircons from a metasedimentary gneiss (Shawsheen Gneiss) that give an upper concordla intercept of $2042 \mathrm{Ma}$. Hill et al. (1984a) interpreted Nd 1sotope data to indicate that the source(s) for the Andover Granite contain a significant component of Proterozolc materlal. Thus; while the terranes appear not to have docked until the Mid-Paleozoic, both appear to contain or to have developed in proximity to an older crustal source. An Archean zircon component in the Permian Narragansett Pier Granite reported by Zartman and Hermes (1984) may have been derived from beneath the Boston-Avalon Zone as a result of the Alleghantan convergence between Africa and North America (Hermes, 1986).

\section{Merrimack Trough}

A1though the metamorphic grade drops abrupt1y west of the Clinton-Newbury fault zone, differences between the Merrimack Trough and the Nashoba Block are not as dramatic as those between the Nashoba Block and the Boston-Avalon Zone. There are a number of general similarities between the metamorphic and plutonic histories of the former pair (Fig. 5). For instance, both experienced major, Middle Ordovician or older andalusitesililmanite type polymetamorphism (Hepburn et al., 1985) and both contain simllar intermediate to mafic calc-alkaline plutons of Ordovician-Silurian age (Hon et al.., 1986). Current uncertaintles in the ages of the metamorphism in each region permit them to be of the same age, but their contemporaneity remains unproven. The plutons may be slightly older in the Merrimack Trough (473 Ma, 
Exeter Diorite, Gaudete et al., 1984; $450 \mathrm{Ma}$, Newburyport Complex, Zartman and Naylor, 1984) than in the Nashoba Block $(430 \mathrm{Ma}$, Sharpners Pond Diorite, Zartman and Naylor, 1984; $402 \mathrm{Ma}$, Indian Head Hill Pluton, Hill et al., 1984a), but have similar compositions (Hon et al., 1986). Thus, both areas may have been in a similar tectonic setting in the Ordovician-Silurian. It is not clear whether the Nashoba Block and Merrimack Trough represent a single terrane which has been disrupted along the Clinton-Newbury Fault, or whether they were separate terranes joined in the Late Proterozoic or Early to Mid-Paleozoic. Additional constraints on the depositional age of the sediments in both blocks and on the times of metamorphism and plutonism are needed to help resolve this question.

\section{Concluding Remarks}

The recognition of "Avalonian" terrane fragments in North America rests in large part upon distinctive Early Paleozoic fossil assemblages in essentially unmetamorphosed sedimentary rocks and on recognition of Late Proterozoic magmatism (e.g. , Rast and Skehan, 1983). The Boston-Avalon Zone (at least Subzones 1 and 3) clearly record these features. However, Late Proterozoic rocks have been recognized to the west of the Boston-Avalon Zone in the Nashoba Block, Merrimack Trough and beyond (1.e., Dry Hill Gneiss, central Massachusetts, Zartman and Nay1or, 1984). Whether these Proterozolc ages imply a genetic affinity between Avalon and some or any of the blocks west of the Bloody Bluff Fault is a major unresolved question in the region.

\section{ACKNOWLEDGEMENTS}

This paper was presented at a symposium on Avalonian Terranes in the Northern Appalachians, and we thank Sandra Barr and the Atlantic Geoscience Society for organizing and hosting the meeting. Our terrane studies have been greatly aided by the interaction with colleagues provided by this symposium, by IGCP Projects 27 and 233, and by the Penrose Conference on Terranes in CircumAtlantic Paleozoic Orogens. We thank 0.D. Hermes and J.W. Skehan, S.J. for their constructive reviews of this paper. We gratefully acknowledge financial support from NSF grants EAR-8212760 to $\mathrm{JCH}$ and $\mathrm{RH}$ and $\mathrm{EAR}-8212761$ to $\mathrm{MH}$; and a grant to $\mathrm{MH}$ from the Northeastern University Research and Development Fund.

ABU-MOUSTAFA, A. and SKEHAN, J.W., S.J. 1976. Petrography and geochemistry of the Nashoba Formation, east-centra1 Massachusetts. In Studies In New England Geology. Edited by P.C. Lyons and A.H. Brownlow. Geological Society of America, Memoir 146, pp. 31-70.

ALEINIKOFT, J.N., ZARTMAN, R.E. and LYONS, J.B. 1979. U-Th-Pb geochronology of the Massabesic Gnetss and the granite near Milford, south-central New Hampshire: new evidence for Avalonian basement and Taconic and Alleghanian disturbances in eastern New England. Contributions to Mineralogy and Petrologg, 71, pp. 1-11.

BAILEY, R.H. 1984. A Precambrian continent margin sequence (slope deposits and ollstostromes): Boston North Quadrangle, Massachusetts. In Geology of the Coastal Lowlands: Boston, Massachusetts to Kennebunk, Maine. Edited by L. Hanson. 76th Annua1 Meeting, New England Intercolleglate Geologica1 Conference, Department of Geological Sciences, Salem State College. Salem, Massachusetts, pp. 145-164.
BAILEY, R.H., SKEHAN, J.W., S.J., DREIER, R.B., and WEBSTER, M. 1987. In review. Olistostromes of the Avalonian Terrane of southeastern New England. In Melanges and 011stostromes of the U.S. Appalachians. Geological Soclety of America, Memoir.

BAROSH, P.J., FAHEY, R.J. and PEASE, M.H., JR. 1977. Preltmtnary compliation of the bedrock geology of the land area of the Boston $2^{\circ}$ sheet, Massachusetts, Connect1cut, Rhode Island, and New Hampshire. United States Geological Surveg, Open File Report 77-285, $91 \mathrm{p}$.

BELL, K.G. and ALVORD, D.C. 1976. Pre-Silurian stratigraphy of northeastern Massachusetts. Geological Soclety of America, Memoir 148, pp. 179-216.

BELL, K., BLENKINSOP, J, and STRONG D.F. 1977. The geochronology of some granitic bodies from eastern Newfoundland and its bearing on Appalachian evolution. Canadian Journal of Earth Sciences, 14, pp. 456-476.

BESANCON, J.R., GAUDETTE, H.B. and NAYLOR, R.S. 1977. Age of the Massabesic Gneiss, southeastern N.H. Geological Soclety of America, Abstracts w1th Prograns, 9, p. 242.

BILLINGS, M.P. 1976. Geology of the Boston Basin. In Studies In New England Geology. Edited by P.C. Lyons and A. Brownlow. Geological Society of America, Memoir 146, pp. 530 .

BOTHNER, H.A., BOJDETTE, B.L., FAGAN, T.J., GAUDETTE, H.E., LAIRD, J. and OLSZEWSKI, W.J., JR. 1984. Geologic framework of the Massabesic Anticlinorium and the Merrimack Trough, southeastern New Hampshtre. In Geology of the Coasta1 Lowlands: Boston, Massachusetts to Kennebunk, Maine. Edited by L. Hanson. 76th Annual Meeting, New England Intercolleglate Geological Conference, Department of Geological Sclences, Salem State College, Salem, Massachusetts, pp. 186-206.

CASTLE, R.O. 1964. Geology of the Andover Granite and surrounding rocks, Massachusetts. United States Geological Survey. Open File Report, 550 p.

CASTLE, R.O. and THEODORE, T.G. 1972. Some genetic Implications of the phase composition of a simple New England pegmatite. U.S. Geological Survey, Professional Paper 800-B, pp. B105-B117.

COLEMAN-SADD, S.P. 1980. Geology of south-central Newfoundland and evolution of the eastern margin of Iapetus. American Journal of Sclence, 280-A pp. 991-1017.

DALLMEYER, R.D. 1982. $40 \mathrm{Ar} / 39 \mathrm{Ar}$ ages from the Narragansett Basin and southern Rhode Island basement terrane: their bearing on the extent and timing of Alleghanian tectonothermal events in New England. Geological Society of America Bullet1n, 93, pp. 1118-1130.

DALLMEYRR, R.D., ODOM, A.L., O'DRISCOLL, C.F., HUSSEY, E.M. and O'BRIEN, S.J. 1980. Chronology of 1gneous and metamorphic events in the southwestern Avalon Zone of the Newfoundland Appalachians. Geological Society of America, Abstracts with Programs, 12, p. 410.

DINITTO, R., HEPBURN, J.C., CARDOZA, K.D. and HILL, M. 1984. The Marlboro Formation in 1ts type area and associated rocks just west of the Bloody Bluff Fault zone, Marlborough area, Massachusetts. In Geology of the Coastal Lowlands: Boston, Massachusetts to Kennebunk, Maine. Edited by L. Hanson. New England Intercolleglate Geological Conference, Department of Geological Sclences, Salem State College, Salem, Massachusetts, pp. 271-291.

DREIER, R.B. 1983. The Blackstone Serles: evidence for Avalonian tectonics in northern Rhode Island. Geological Soclety of America, Abstracts with Programs, 15, p. 129.

DURFEB CARDOZA, K. HEPBURN, J.C. and HON, R. 1987. Geochemistry of the Brighton Volcanics. Boston Basin, eastern Massachusetts. Geological Society of America, Abstracts with Programs, $19, \$ 1, \mathrm{p} .12$.

GARDNER, J.N., GOFF, F., GARCIA, S. and HAGAN, R.C. 1986. Stratigraphic relations and 1ithologic varlations in the Jemez Volcanic fleld, New Mexico. Journal of Geophysical Research, 91. pp. 1763-1778.

GATES 0. and MOENCH, R.H. 1981. Bimoda1 Silurian and Lower Devonian volcantc rock assemblages in the Machias-Eastport area, Maine. United States Geological Survey, Professional Paper 1184, $32 \mathrm{p}$.

GAUDETTR, H.E.. BOTHNER, W.A., LAIRD, J., OLSZEWSKI, W.J., JR. and CHEATHAM. M.M. 1984. Late Precambrian/Ear1y Paleozolc deformation and metamorphism in southeastern New Hampshire confirmation of an exotic terrane. Geological Society of America, Abstracts with Programs, 16. p. 516.

GREW, E.S. and DAY, H.W. 1972. Staurolite, kyanite and silimanite from the Nerragansett Basin of Rhode Island. United States Geological Survey, Professiona1 Paper 800-D, pp. D151-D157.

HALL, L.M. and ROBINSON, P.R. 1982. Stratigraphic-tectonic subdivisions of southern New England. In Major structural zones and faults in the Northern Appalachians. Edited by $P$. St-Julien and J. Beland. Geological Association of Canada, Spec1a1 Paper 24. pp. 15-41. 
HANDFORD, L.S., FAIRBAIRN, H.W., PINSON, W.A. and HURLEY, P.M. 1965. Rb-Sr whole rock age study of the Andover and Chelinsford Granites, Massachusetts. In 13th Annual Progress Report, United States Atomic Energy Commission, No. 1381-13. Edited by P.M. Hurley. Massachusetts Institute of Technology. Cambridge, Massachusetts, pp. 11-14.

HEPBURN, J.C. and DINITTO, R.G. 1978. Preliminary bedrock geologic map of the Marlborough Quadrangle, Worcester and Middlesex Counties, Massachusetts. United States Geological Survey, Open F1le Map and Text, $\$ 78-222,29 \mathrm{p}$.

HEPBURN, J.C., LUX, D.R. and HILL, M. 1987. ${ }^{40} \mathrm{Ar} / 39 \mathrm{Ar}$ Carbontferous cooling ages from the Nashoba Terrane, eastern Massachusetts. Geological Society of America, Abstracts with Programs, 19,11, p. 18 .

HEPBURN, J.C. and MUNN, B. 1984. A geologte traverse across the Nashoba Block. Bastern Massachusetts. In Geology of the Cosstal Lowlands: Boston, Massachusetts to Kennebunk, Maine. Edited by L. Hanson. 76th Annual Meeting, New England Intercollegiate Geological Conference, Department of Geological Sciences, Salem State College, Salem, Massachusetts, pp. 103123.

HEPBURN, J.C., OLSZEWSKI, W.J. , JR. and GUIDOTTI, C.V. 1985. Metamorphism of tectonic terranes in the eastern marginal zone of the Appalachian orogen. New Bngland. Geological Society of America, Abstracts with Programs, 17. p. 608.

HEPBURN, J.C. and REHMER, J. 1981. The diagenetic to metamorphic transition in the Narragansett and Norfolk Basins. Massachusetts and Rhode Island. In Guidebook to Geological Field Studies in Rhode Island and Adfacent Areas. Edited by J.C. Boothroyd and 0.D. Hermes. 73rd New England Interco1leglate Geologic Conference, Department of Geology. University of Rhode Island, Kingston, R.I., pp. 47-65.

HERMES, 0.D. 1986. Role of 1gneous rocks in terrane analysis: application to geological evolution of the New England Avaion (abs.). Maritime Sediments and Atlentic Geology, 22, p. 190. HERMES, 0.D., GROMET, L.P. and ZARTMAN, R.B. 1981. Zircon geochronology and petrology of plutonic rocks in Rhode Island. In Guidebook to Geologic Field Studies in Rhode Island and Adjacent Areas, Edited by J.C. Boothroyd and O.D. Hermes. 73rd New England Intercollegiate Geologic Conference, Department of Geology. University of Rhode Island, Kingston, Rhode Island, pp. 315-338.

HERMES, O.D. and ZARTMAN, R.B. 1985. Late Proterozo1c and Devonian plutonic terrane within the Avalon Zone of Rhode Island. Geological Society of America Bulletin, 96. pp. 272-282

HILL, M.D. 1985. Intermediate composition plutons of the Nashoba Terrane, eastern Massachusetts. Geological Soclety of America, Abstracts with Programs, 17, p. 24.

HILL, M., HEPBURN, J.C.. COLLINS, R.D. and HON, R. $1984 a$. Igneous rocks of the Nashoba Zone, Eastern Massachusetts. In Geology of the Coasta1 Lowlands: Boston, Massachusetts to Kennebunk, Malne. Edited by L. Hanson. 76th Annual Meeting, New England Intercollegiate Geological Conference, Department of Geological Sciences, Salem State College. Salem, Massachusetts, pp. 61-80.

HILL, M., HEPBURN, J.C. and DURFER. K.D. 1984b. Isotope and trace element geochemistry of mafic volcanic and intermediate plutonic rocks from the Nashoba Terrane, Eastern Massachusetts. Geological Society of America, Abstracts with Programs, 16. p. 25.

HILL. M. and ROSS, M.E. 1983. Rb-Sr and Sm-Nd study of crustal xenoliths and megacrysts from a camptonite dike in Cambridge. Massachusetts. Geological Society of America, Abstracts with Programs, 15. p. 135 .

HON, R., DILLON, P., HILL, M. and HEPBURN, J.C. 1984. Late Precambrian magmatism of the Avalon Boston Platform, southeastern New England. Geological Soclety of America, Abstracts with Programs, 16, p. 25.

HON R. HEPBURN, J.C. BOTHNER, W.A. OLSZEWSKI, W.J. GAUDETTE, H.E., DENNEN, W.H. and LOFTENIUS, C. 1986. MidPaleozoic calc-alkaline rocks of the Nashoba Block and Merrlmack Trough. In Guldebook for Fleld Trips in Southwestern Maine. Edited by D.W. Newberg. 78th New England Intercollegiate Geological Conference, Bates College, Lewiston, Maine, pp. 37-52.

HON, R., and THIRLWALL, M.F. 1985. Newbury Volcanics - a Late Silurian island arc(?). Geological Soclety of America, Abstracts with Programs, 17, p. 25.

HURLEY, P.M. and SHEARER, C.K. 1981. Paleomagnetic Investigations in 1gneous-metamorphic rock units in eastern New England. Canadian Journal of Earth Sciences, 18, pp. 1248-1260.

KAYB, C.A. and ZARTMAN, R.F. 1980. A Late Precambrian to Cambrian age for the stratified rocks of the Boston Basin, Massachusetts. In Proceedings of the Caledonides in the U.S.A. Edited by D.R. Wones. International Geological Correlation Project 27, Virginia Polytechnical Institute and
State University, Memoir 2, pp. 257-262.

KELLY, W.J., OLSZEWSKI. W.J., JR, and GAUDETTE, H.E. 1980. The Massabesic orthogneiss, southern New Hampshtre. Geological Soc1ety of Amer1ca, Abstracts with Programs, 12, p. 45.

KEPPIB, J.D. 1985. The Appalachlan collage. In The Caledonide Orogen, Scandinavia and Related Areas, Edited by D.G. Gee and B. Sturt. John Wiley \& Sons Publishers, New York.

LE FORT. P. 1981. Manaslu leucogranite: a collision signature of the Himalaya; a model for 1ts genesis and emplacement. Journal of Geophysical Research, 86, pp. 10545-10568.

LENK, C. STROTHER, P.K., KAYB, C.A. and BARGHOORN, B.S. 1982. Precambrian age of the Boston Basin: new evidence from fossils. Science, 216. pp. 619-620.

LYONS, J.B. BOIJETTE, E.L. and ALEINTKOFF, J.N. 1982. The Avalonian and Gander Zones in central New England. In Major Structural Zones and Faults of the Northern Appalachlans, Edited by P. St-Julien and J. Beland. Geological Association of Canada, Special Paper 24, pp. 43-66.

NAYLOR, R.S, and SAYER, S. 1976. The Blue Hills Igneous Complex, Boston area, Massachusetts. In Geology of Southeastern New England: A Guddebook for Fleld Trips to the Boston Area and Vicinity. Edited by B. Cameron. 68th New England Intercollegiate Geological Conference, Department of Geology, Boston Un1vers1ty, Boston, Massachusetts, pp. 135146.

NOYES, H.J., WONES, D.R. and FREY, F.A. 1983a. A tale of two plutons: petrographic and mineralogic constraints on the petrogenesis of the Red Lake and Eagle Peak plutons, central Sterra Nevada, California. Journal of Geology. 91. pp. 353379.

NOYES, H.J., FREY, F.A. and WONES, D.R. 1983b. A tale of two plutons: geochemical evidence bearing on the origin and differentiation of the Red Lake and Eagel Peak plutons, central Sierra Nevada, California. Journal of Geology, 91, pp. 487-509.

O'BRIEN, S.J., WARDLR, R.J. and KING, A.F. 1983. The Avalon Zone: a Pan-African terrane in the Appalachian Orogen of Canads. Geological Journa1, 18, pp. 195-222.

O'HARA, K. and GROMET, L.P. 1983. Textural and Rb-Sr isotopic evidence for Late Paleozolc mylonitization within Honey yill fault zone, southeastern Connecticut. American Journal of Science, 283, pp. 762-779.

O'HARA, K. and GROMET, L.P. 1985. Two distinct Late Precambrian (Avalonian) terranes in southeastern New England and their Late Paleozoic fuxtaposition. American Journal of Science, 285, pp. 673-709.

OLSZEWSKI. W.J., JR. 1980. The geochronologg of some stratifled metamorphic rocks in northeastern Massachusetts. Canadian Journal of Earth Sciences, 17, pp. 1407-1416.

OLSZEWSKI, W.J. , JR., GAUDETTE, H.E., BOTHNER, W.A., LATRD, J. and CHEATHAM, M.M. 1984. The Precambrian (?) rocks of southeastern New Hampshire - a forgotten land. Geological Society of America, Abstracts with Programs, 16, p. 54

PAVLIDES, L. 1981. The central Virginia volcanic-plutonic be1t: an island arc of Cambrian (?) age. United States Geological Survey, Professional Paper 1231-A, 34 p.

PITCHER, W.S. 1982. Granite type and tectonic environment. In Mountain Bullding Processes. Edited by K.J. Hsu. Academic Press, London, pp. 19-40.

RAST, N. and SKRHAN, J.W., S.J. 1981. The geology of the Precambrian rocks of Newport and Middletown, Rhode Island. In Guldebook to Geologic Fleld Studies in Rhode Island and Adjacent Areas. Edited by 0.D. Hermes and J.C. Boothroyd. 73rd Annual Meeting, New England Intercolleglate Geological Conference, Department of Geology, University of Rhode Island. Kingston, Rhode Island, pp. 67-92.

RAST, N. and SKEHAN, J.h., S.J. 1983. The evolution of the Avalonian plate. Tectonophysics, 100, pp. 257-286.

REHMER, J. 1980. The Squantum tillold member of the Roxbury Conglomerate of Boston, Massachusetts. In Earth's PrePleistocene Glacial Record. Edited by M.J. Hambrey and W.B. Harland. International Geologica1 Correlation Project 38. Cambridge University Press, pp. 756-759.

REHMER, J.A. and ROY, D.C. 1976. The Boston Bay Group: the boulder bed problem. In Geology of Southeastern New England: A Guidebook for Field Trips to the Boston Area and Vicinity. Edited by B. Cameron. 68th Annual Meeting. New England Intercolleglate Geological Conference, Department of Geology, Boston University, Boston, Massachusetts, Science Press. Princeton, New Jersey, pp. 71-91.

ROBINSON, P. 1983. Realms of regional metamorphlsm in southern New England, with emphasis on the eastern Acadian metamorphtc high. In Regional Trends in the Geology of the AppalachianCaledonian-Hercynian-Mauritanlde Orogen. Edited by P.E. Schenk. NATO Advanced Sclence Institutes Series, D. Re1de1 Publishing Company, Dordrecht, pp. 249-258.

SAHAGIAN, G. and HON, R. 1985. Geochemical and petrological nature of the Precambrian (?) gabbro-basaltic terrane of 
eastern Massachusetts. Geological Society of America Abstracts w1th Programs, 17, 1, p. 62 .

SCHUTTS, L.D. , BRECHER, A., HURLEY, P.M. , MONTGOMERY, W. and KRUEGER, H.W. 1976. A case study of the time and nature of paleomagnetic resetting in a mafic complex in New England. Canadian Journal of Earth Sciences, 13, pp. 898-907.

SHERIDAN, A.W., HON, R. and HEPBURN, J.C. 1987. The Milford Pluton: evidence for crustal diversity within the Avalonian Terrane in eastern Massachusetts. Geological Society of America, Abstracts with Programs, 19, \$1, p. 56

SHRIDE, A.F. 1976. Stratigraphy and correlation of the Newbury Volcanic Complex, northeastern Massachusetts. Geological Soclety of America, Memolr 148, pp. 147-177.

SKEHAN, J.W., S.J. 1968. Fracture tectonics of southeastern New England as illustrated by the Wachusett-Marlborough Tunne1, east-central Massachusetts. In Studies of Appalachian Geology, Northern and Maritime. Edited by E-An Zen et al. John W1ley \& Sons, Inc. , New York, pp. 281-290.

SKEHAN, J.W., S.J. and ABU-MOUSTAFA, A.A. 1976. Stratigraphic analysis of rocks exposed in the Wachusetts-Marlboroug tunne1, east-central Massachusetts. Geological Society of Amer1ca, Memoir 148, pp. 217-240.

SKEHAN, J.W., S.J., BAIIEY, R.H., DREIER, R.B. and WEBSTER, M.J. 1985. Late Proterozoic ollstostromes of the Avalon Zone, southeastern Massachusetts and Rhode Island. Geological Society of America, Abstracts with Programs, 17, p. 719.

SKEHAN, J.W., S.J. and RAST, N. 1983. Relationship between Precambrian and Lower Paleozolc rocks of southeastern New England and other North Atlantic Avalonian terranes. In Regional Trends in the Geology of the Appalachian-CaldeontanHercynian-Mauritanide Orogen. Edited by P.E. Schenk. NATO Advanced Sclence Institutes Serles, D. Reidel Publishing Co., Dordrecht, pp. 131-162.

SMITH, C. and HON, R. 1984. Geology, petrology and origin of the Precambrian igneous rocks located in the area north of Bostion. In Geology of the Coastal Lowlands: Boston, Massachusetts to Kennebunk, Maine. Edited by L. Hanson. 76th Annua1 Meeting. New England Intercolleglate Geological Conference, Department of Geological Sciences, Salem State College, Salem, Massachusetts, pp. 292-309.

STRONG D.F., O'BRIEN, S.J. TAYLOR, S.W., STRONG, P.G. and WILTON, D.H. 1978. Aborted Proterozolc rifting in eastern Newfoundland. Canadian Journal of Earth Sclences, 15, pp. 117-131.

THOMPSON, M.D. 1985. Evidence for a Late Precambrian caldera in Boston, Massachusetts. Geology, 13, pp. 641-643.

WILLIAMS, H. and HATCHER, R.D. , JR. 1982. Suspect terranes and accretionary history of the Appalachian Orogen. Geology, 10. pp. 530-536.

WILLIAMS, H. and HATCHER, R.D., JR. 1983. Appalachian suspect terranes. Geological Soclety of America, Memoir 158, pp. 3353.

WILLIAMS, H. and MAX, M.D. 1980. Zonal subdivision and regional correlation in the Appalachian-Caledontan orogen. In The Coledonides in the U.S.A. Edited by R. Wones. International Geological Correlation Project Proceedings. Project 27. Department of Geological Sclence, Virginia Polytechnic Institute, Blacksburg, Virginia, Memolr 2, pp. 57-62.

WINTSCH, R.P. and SUTTER, J.F. 1986. A tectonic model for the late Paleozolc of southeastern New England. Journal of Geology. 94, Pp. 459-472.

ZARTMAN, R.E. 1977. Geochronology of some alkallc rock provInces in eastern and central United States. Annual Review of Earth and Planetary Sclences, 5, pp. 257-286.

ZARTMAN R.E and HERMES, 0.D. 1984. Evidence from inhertted zircon for Archean basement under the southeastern New England basement. Geological Society of America, Abstracts with Programs, 16, p. 704.

ZARTMAN, R.E., HURLEY, P.M., KRUEGER, H.W. and GILLETTI, B.J. 1970. A Permilan disturbance of K-Ar radiometric ages in New England: 1ts occurrance and cause. Geological Soclety of America Bulletin, 81, pp. 3359-3374.

ZARTMAN, R.E. and MARVIN, R.F. 1971. Radiometrlc age (Late Ordovician) of the Quincy, Cape Ann, and Peabody Granites of eastern Massachusetts. Geological Society of America Bulletin, 82, pp. 937-958.

ZARTMAN, R.E. and NAYLOR, R.S. 1984. Structural implications of some radiometric ages of igneous rocks in southeastern New England. Geological Society of America Bulletin, 95, pp. 552539.

ZEN, E-AN, editor. 1983a. Bedrock Geolocic Map of Massachusetts, United States Geological Survey, Scale $1 / 250,000$

ZEN, B-AN. 1983b. Exotc terranes in the New England Appalachians - 1tmits, candidates, and ages: a speculative essay. In Contributions to the Tectonics and Geophysics of Mountatn Chains. Edited by R.D. Hatcher, Jr.. H. WI11lams, and I. Zietz. Geologtcal Soclety of America, Memoir 158, pp. 55-81. 